\title{
HISTORY, ORAL TRANSMISSION AND STRUCTURE IN IBN KHALDUN'S CHRONOLOGY OF MALI RULERS
}

\author{
Ralph A. Austen \\ University of Chicago \\ Jan Jansen \\ University of Leiden
}

The early history of the Mali empire is known to us from two sources: Mande oral literature (epic and praise poetry) recorded over the last 100 years and Ibn Khaldun's Kitab al-cIbar (Book of Exemplars) written in the late fourteenth century. ${ }^{1}$ The list of Mali kings presented by Ibn Khaldun is precise, detailed, entirely plausible, and recorded not too long after the events it purports to describe. For scholars attempting to reconstruct an account of this West African empire, no other medieval Arab chronicler or, indeed, any Mande oral traditions provide comparable information for its formative period.

There is, however, reason to question the historical reliability of Ibn Khaldun's account precisely on the grounds of its narrative richness. When read in relation to the general model of political development and decay which Ibn Khaldun worked out in the more theoretical Muqaddimah ("Prolegomena") of Kitab al-cIbar, as well as the larger context of the work in which it is imbedded, the Mali kinglist takes on some characteristics of an instructive illustration rather than a fully empirical account of the past. Indeed Ibn Khaldun himself, in his contemplation of the basis for asabiyah (group solidarity) among bedouin peoples, cautions us against literal interpretation of genealogical accounts:

For a pedigree is something imaginary and devord of reality. Its usefulness consists only in the resulting connection and close contact. $^{2}$

Ibn Khaldun is certainly not as ideologically engaged in constructing the royal genealogy of Mali as a bedouin spokesman might be in reciting the list of his own ancestors. Nevertheless, this great Arab thinker has something at stake in this story which needs to be given serious attention by all scholars concerned with either the events of the medieval western Sudan or the process by which they have been incorporated into more recent narratives.

History in Africa 23 (1996), 17-28. 
Historians from Delafosse through Niane to Levtzion and Ly-Tall have blended the very stylized oral traditions of Mali with the apparently more mundane narrative of Ibn Khaldun to produce an account of the early Mali empire which is now quite standardized. ${ }^{3}$ For instance, almost everyone accepts Delafosse's view of Sunjata as a historical ruler of the thirteenth century. Many doubts have, of course, been raised about the details of this historiography, but Ibn Khaldun himself seems to have been exempted from most of this scrutiny.

In a recent conference on the Sunjata epic, scholars in the fields of both history and oral literature debated at some length the historicity of both contemporary Mande oral tradition and Ibn Khaldun's kinglist. ${ }^{4}$ The focus of this discussion, however, was on the identity of Ibn Khaldun's informant (or informants) and the kind of oral tradition they may themselves have been carrying from Mali to North Africa. ${ }^{5}$ All of the participants ${ }^{6}$ tacitly accepted the idea that Ibn Khaldun had faithfully transcribed the information passed on to him.

It is this last presupposition which must now be subjected to critical examination. We actually know a great deal more about Ibn Khaldun than about "Sheikh Uthman" and the other figures who link him with fourteenthcentury Mali traditions. What is important from the present perspective about these informants is that there were at least four or five of them, so that we may presume that Ibn Khaldun enjoyed some freedom (or was under constraint) to construct his own version of early Malian history. ${ }^{7}$ We know more precisely what ideas Ibn Khaldun held about the rise and decline of ruling dynasties. As will be shown, these ideas are strongly reflected and even underlined in his account of the Mali empire.

The outline of this account is presented in the following table based on Levtzion (1973, p. 71).
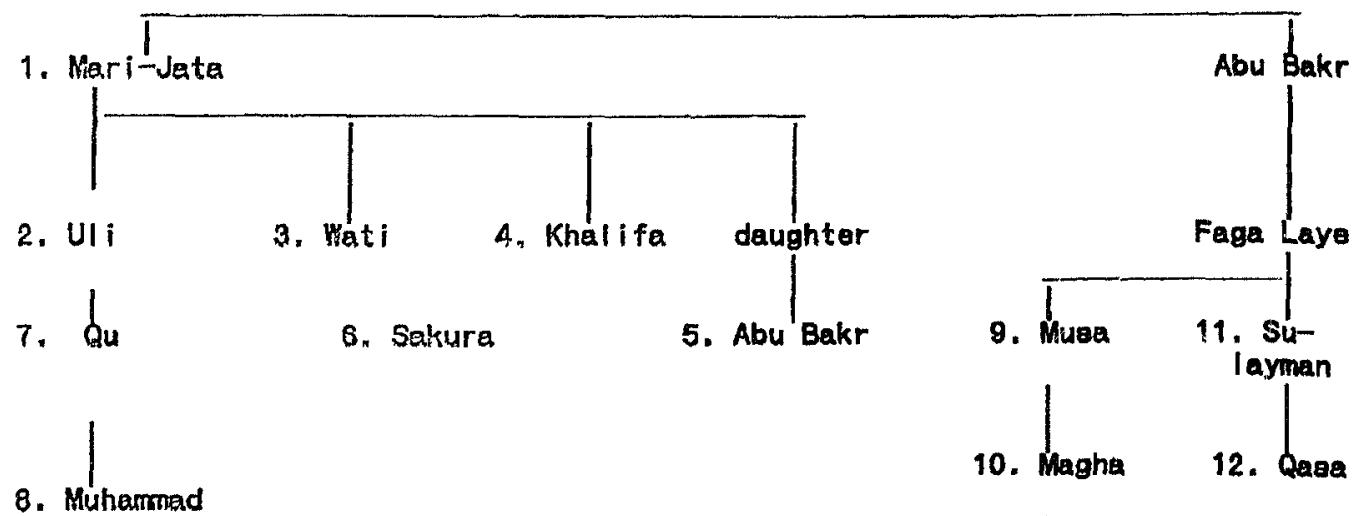

8. Muhammad

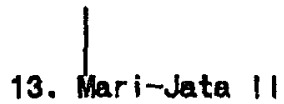


Mar1-Jata (usually 1dentified with the Sunjata of oral texts) is succeeded by three of his sons Ul1, Wat1, and Khalifa These three brothers are succeeded by Abu Bakr, a son of Mart-Jata's daughter Abu Bakr is succeeded by Sakura, a mawla ("client," probably meaning a freed slave or descendant of slaves)

Sakura is not succeeded by his own kin, but by Qu, son of Uli and thus grandson of Mart-Jata Qu is succeeded in turn by his son Muhammad Then the rule moves to a different dynastic branch, since Muhammad's successor, Musa, is sard to be a grandson of another Abu Bakr, Man-Jata's younger brother, who never himself occupied the throne ${ }^{8}$ This ninth ruler is the famous Mansa Musa, known for his luxurious pilgrimage to Mecca, and thus documented in numerous Arabic texts as well as the Cresque map of Africa found, among other places, on the cover of Levtzion's 1973 book

Musa is succeeded first by his son Magha, then by his younger brother Sulayman, who is succeeded by his son Qasa, and he by Marn-Jata II, son of Magha and grandson of Musa Mari-Jata II had just died at the tume Ibn Khaldun collected a detarled account of his reign

After Mari Jata II, the succession falls into chaos with four different rulers in seventeen years The two sons of Man Jata II are weak figures dominated by their viziers, one of whom ultımately takes the throne himself, to be succeeded by a man "who claimed descent of Marı Jata "We know little about this last ruler, Magha III Ibn Khaldun seems to have no information about his demise but independent sources indicate that by this time the power of Mali itself was in irreversible decline ${ }^{9}$

This last section of Ibn Khaldun's account is not included in the table above nor in the analysis which follows below It is probably the most empirically accurate part of the text because it refers to events during Ibn Khaldun's own lifetıme, known to him from first-hand informants rather than multiple oral accounts at several removes from their occurrence Thus it at once confirms and contradicts Ibn Khaldun's theory of cyclical dynastic change It confirms the theory by presenting a picture of the disorder which must ensue when a dynasty has run its course fully, but because it is known in such detail, the internal narrative of this last period cannot be shaped to fit Ibn Khaldun's cyclical model Our analysis must thus focus on the earlier, less reliably, documented, but histoncally most critical, of the Malı kings

\section{III}

According to Ibr Khaldun's account, rule in the Malı empire moved from patrilineal group to patrilineal group withın the same larger lineage Such a cycle resembles the model established in the Muqaddimah But before discussing that model it is important to note the cyclical pattern within the Malian kinglist, taking into account the characteristics assigned to each incumbent of the imperial throne 


\section{Cycle 1}

1. Mari-Jata I

2. Uli

3. Wat

4. Khalifa

\section{Cycle 2}

5. Abu Bakr

6. Sakura

7. $\mathrm{Qu}$

8. Muhammad

\section{Cycle 3}

9. Musa

10. Magha

11. Sulayman

12. Qasa

\section{Mari-Jata II}

Three cycles of four to five names can be seen between Mari-Jata I and Mari-Jata II. Mari-Jata I is a good father who is succeeded by three sons. The first son, Uli, is a good king. Nothing is said about the second successor, Wati, and the third son, Khalifa, is a bad king. This third son is succeeded by Abu Bakr, a son of Mari-Jata's daughter.

Abu Bakr is succeeded by Sakura (no. 6), a freed slave, with whom the second cycle begins. Sakura is a good and powerful king who goes on pilgrimage to Mecca. On his way back to Mali he is killed. His successor is Qu, Uli's son, who is succeeded by his own son Muhammad.

The third cycle starts after Muhammad. Muhammad is succeeded by Mansa Musa, who is said to be a grandson of Mari-Jata's younger brother, an Abu Bakr who never took the throne. ${ }^{10}$ Musa stands at the beginning of a cycle of five names. This cycle ends with the Mari-Jata II, who is also described by Ibn Khaldun as a bad king.

The three cycles have much in common although the second is somewhat different from the other two. Each is initiated by a good king: Mari-Jata, Sakura, and, finally, Musa. Those kings do great things. Mari-Jata founds the empire, Sakura restores it to power, and both Sakura and Musa make pilgrimages to Mecca. Musa equals Mari-Jata I in longevity, both reigning 25 years.

Succession within the cycles follows patrilineal principles. After each good king come two or three kings whose claims to succession are unchallenged, since they are all legitimate patrilineal descendants of Mari-Jata I. The cycles are initiated by figures with less orthodox claims to succession. Mari Jata, of course, has no claim to succession, since he is, in Ibn Khaldun's terms, the founder of the dynasty. ${ }^{11}$ Each of the two Abu Bakrs serves as a kind of intermediary between different cycles. In the first case Abu Bakr is a king to whom Ibn Khaldun does not give any notable characteristics. His presence in the dynastic succession explains to Ibn Khaldun why a good slave could seize power. Since Abu Bakr does not actually belong to the royal patrilineage, Sakura had a valid reason to revolt; he also becomes the (apparently inadvertent) agent of a return to proper patrilineal succession. The 
second Abu Bakr is thus no more than a legitimizing factor, since his name is used to connect the powerful Musa to a royal descent group whose living members are not his parents or siblings.

The cycles all lead from political strength to decadence. By three generations after every "good king" there is a break in the direct succession; in two out the three cases, the cause of this break is a manifestly bad ruler. One may bring some nuances into the manner in which reigns are counted. It can be argued, for instance, that Sulayman's successor Qasa should be neglected, since he is said to have ruled only a few months. This would reduce the third cycle from five to four kings. Sakura, the true founder of the second cycle, has only two successors before the next break occurs. However, such a recounting does not undermine the cyclical character of rule in the kinglist. In fact, as shown below, it actually brings it closer to Ibn Khaldun's general model of the downward path followed by every ruling dynasty.

\section{IV}

This repeating cycle of Malian rulers conforms in most critical respects to Ibn Khaldun's own views on the cyclical development of dynastic states. The major divergence is that the Malian succession often passes through brothers, whereas Ibn Khaldun bases his theory upon a concept of successive generations. He thus claims in effect that all governments decay within four generations of single ruling lineage. This cycle consists of the founder, the maintainer, the imitator, and the destroyer. Then another lineage within the same family replaces the ruling patrilineage. In the Muqaddimah he explains this process quite explicitly:

[The prestige of a dynasty] reaches its end in a single family within four successive generations. This is as follows: The builder of the family's glory knows what it costs him to do his work, and he keeps the qualities that created his glory and made it last. The son who comes after him had personal contact with his father and thus learned those things from him. However, he is inferior to him in this respect, inasmuch as a person who learns things through study is inferior to a person who knows them from personal application. The third generation must be content with imitation and, in particular, with reliance upon tradition. This member is inferior to him of the second generation, inasmuch as a person who relies upon tradition is inferior to a person who exercises independent judgement.

The fourth generation then is inferior to the preceding ones in every respect. Its member has lost the qualities that preserved the edifice of its glory... He keeps away from those in whose group solidarity $^{12}$ he shares, thinking he is better than they. He trusts [that they will obey him because] he was brought up to take their obedience for granted, and he does not know the qualities that made obedience necessary...Therefore, he considers them despicable and 
they, in turn revolt against him and despise him. They transfer their allegiance from him and his direct lineage to some other related branch, in obedience to their group solidarity, after they have convinced themselves that the qualities of the [new leader] are satisfactory to them. His family then grows whereas the family of the original [leader] decays and the edifice of his 'house' collapses. ${ }^{13}$

Ibn Khaldun does not consider this cycle of four generations as an absolutely fixed rule. Variations are possible, since he goes on to note: ${ }^{14}$

The rule of four [generations] with respect to prestige usually holds true. It may happen that a 'house' is wiped out, disappears, and collapses in fewer than four, or it may continue unto the fifth and sixth generations, although in a state of decline and decay. The four generations can be defined as the builder, the one who has personal contact with the builder, the one who relies on tradition, and the destroyer.

\section{V}

Ibn Khaldun's theoretical position on dynastic rule is not fully supported by his chronology of the Mali empire, since several of the figures in each line of rulers belong to the same generation as their predecessors. Nonetheless, the pattern of rise and fall seems to fit the scheme laid out in the Muqaddimah. The first cycle of kings shows both the pattern and the variance: father MariJata I; followed by three sons (i.e., all brothers to one another); a good ruler, one without discernible qualities; and a bad one. The last/bad son receives a great deal of attention from Ibn Khaldun, both in the Muqaddimah (see above) and in the account of Mali where the misdeeds of Khalifa and his counterpart, Mari-Jata II, are described in detail.

The other two cycles are variations of this model of increasing decay. They correspond in number and kinship relation with the pattern that is predicted by Ibn Khaldun. Rulers within one cycle are connected by intimate bonds of kinship - they form a restricted patrilineage. Rule in these patrilineages shows the same process of decay: the last king on our version of the list, Mari Jata II, is number five (or four) in the cycle and a notoriously bad king. There is no indication in the description of its last ruler of why the second cycle decayed, but the eventual descent of rule into the hands of a slave is (particularly for someone like Ibn Khaldun, living in an era of Middle Eastern servile dynasties) sufficient evidence of its weakness.

The cyclic character of Ibn Khaldun's model is clearly shown from the kings who are said to have made pilgrimages. This habit is, of course, positively valued by Ibn Khaldun. He attributes the pilgrimage only to kings who start the cycle. However, it is plausible that other kings also made the trip to Mecca, because Mali rulers appear in general to have been quite committed to maintaining their Islamic identity. 
Ibn Khaldun seems convinced about the validity of his own model. This may explain why he pays no attention to Ibn Battuta's unfavorable report of Sulayman, Musa's successor, as a "miserly king," unpopular with his subjects. ${ }^{15}$ All that Ibn Khaldun says about Sulayman is that he reigned 24 years. In Ibn Khaldun's system of values this number represents a positive judgment; it is, in fact, only one year less than the reign of Musa himself. Again, the second ruler in the cycle maintains the prestige of the dynasty, but does not quite equal the founder.

Aside from the generational vs. collateral issue, the only deviation in the story of the early Mali dynasties from Ibn Khaldun's ideal image is the position of Sakura, a ruler who was a freed slave and not a descendant of MariJata I. Moreover, Sakura is the second, not the first ruler in the cycle whose strength derives from him. As has been noted, Sakura's rule is legitimized by placing Abu Bakr, a matrilineal (and thus ineligible for succession) descendant of Mari-Jata, at the beginning of this cycle. The mention of Sakura might show how Ibn Khaldun was trying to incorporate the data he had collected, since he may have heard that one king was of slave origin.

It is plausible that Ibn Khaldun took the story of Sakura from contemporary Mali oral sources, since Sakura's name can still be found in Mande oral traditions, while the other rulers in Ibn Khaldun's list have been forgotten. ${ }^{16}$ A "Jonni (slave) Sekure" is still remembered as a king of servile origin who is said to have succeeded Sunjata's son. ${ }^{17}$ The oral account is also consistent with the next stage in Ibn Khaldun's genealogy, since the slave ruler is said to be killed and then succeeded by Mari-Jata, Sunjata's grandson. It is remarkable that a ruler descended from slaves with almost the same name is found in both Ibn Khaldun's chronology and twentieth-century Mande oral tradition. On the other hand the seizure of political power by royal slaves would not have been an unfamiliar phenomenon either to Ibn Khaldun or to modern Mande bards. ${ }^{18}$

However, there are also important divergences between the two sets of sources on this episode. First of all, the names of the predecessor and successor of Sakura/Sekure appear, respectively, as Khalifa and Qu in Kitab al-cIbar, but in the local traditions they become Juruninkun and Ko(n) Mamari (of Mamadi). Secondly, in Ibn Khaldun's account Qu succeeds Sakura after the latter dies on his way back from Mecca, while in the oral tradition Kon Mamari himself kills Sekure. Moreover, instead of presenting Sakura as the effective and pious successor to a decadent dynasty, the Mande griots dwell on the events of his assassination. This story is presented as a variant of the "femme fatale motif" found throughout Mande narrative, whereby a hero is brought down through the betrayal of a nubile woman (in this case it is Sekure's daughter who allies herself with Kon Mamadi against her father). ${ }^{19}$ Also, Kon Mamadi replicates Sunjata's own career by returning from exile to claim his usurped inheritance, in this case with a more specific certification of Islamic learning than either Sekure (whom the griots credil with no pilgrimage) or the founder of the Mali empire.

In the case of Sakura (and the Sunjata narrative in general) we must also consider the possibility of feedback from Ibn Khaldun to the later oral 
traditions. ${ }^{20}$ Despite the fact that Ibn Khaldun's works appear to be absent from the syllabus of Sudanic Islamic learning, Kitab al-clbar was known to at least some local ${ }^{c}$ ulama who studied in Egypt or the Maghreb. ${ }^{21}$ The portions of the text dealing with Mali may thus have become more widely diffused in the region as Islamic literacy increased from the late seventeenth century onward and influenced the oral traditions concerning the origins of contemporary ruling dynasties. This speculation is consistent with the absence of Sunjata/Mari Jata from recorded local narratives (written or oral) from the time of Ibn Khaldun until the late nineteenth century. ${ }^{22}$

\section{VI}

Medieval Arab authors writing on politics often used historical examples from their own and other cultures to make points about the qualities of effective and dignified rulership. Ibn Khaldun is usually contrasted with the authors of such "Mirrors for Princes" because he explicitly criticizes their historical methodology and also provides (as in the case of Mali) indications of the sources of his own information. ${ }^{23}$ Yet it is clear that Ibn Khaldun, while not seeking favor with any particular ruler, is writing within the context of the "Mirrors for Princes" tradition. The very title of his major work Kitab al-clbar ("Book of Exemplars" usually mistranslated as "Universal History") quite literally states that the information he presents to us serves a didactic purpose. $^{24}$ The long descriptions of various state offices in those sections of the Muqaddimah which are seldom quoted also attest to this concern with statecraft as does the fact that Ibn Khaldun preceded and followed the writing of this book with a very active role in court politics. ${ }^{25}$

During the period when Ibn Khaldun was writing the Kitab al ${ }^{-}$Ibar, other Islamic authors of more standard didactic works tended to link their advice to and praise of current rulers with extensive historical accounts whose "Iessons" were not always made explicit. ${ }^{26}$ In the Muqaddimah $\mathrm{Ibn}$ Khaldun does criticize the work of earlier historians, but it is important to distinguish between the two principles on which his own historiography is based: "The [writing of history] requires numerous sources and greatly varied knowledge. It also requires a good speculative mind and thoroughness." ${ }^{27}$

The first of these principles does not clearly separate Ibn Khaldun from the general body of medieval Arab scholars who, much as this may astound modern Africanists, were very sensitive to both the collection of oral traditions and the indication of their chains of transmission. ${ }^{28}$ The quality which draws us to Ibn Khaldun rather than his contemporaries is instead his "good speculative mind," i.e., his adherence to our own Greek-based practice of subjecting whatever evidence may be available to formal logical analysis. It is this quality which he (along with modern commentators like E.I.J. Rosenthal) find lacking in other Islamic thinkers of his time:

Historians, Qur'an commentators and leading transmitters have committed frequent errors in the stories and events they reported. 
They accepted them in the plain transmitted form, without regard for its value. They did not check them with the principles underlying such historical situations nor did they compare them with similar material. ${ }^{29}$

In the case of Mali, it appears that Ibn Khaldun has constructed a version of the royal genealogy which best fits his notion of "the principles underlying such historical situations." The narrative also reinforces a political lesson about the cyclic character of rule, although there is a sense in which Ibn Khaldun's belief in the inevitability of dynastic decay undermines the practical value of what he has to teach. It must also be noted that Ibn Khaldun does not establish any explicit connection between the theory expounded in the Muqaddimah, whatever may or may not have been its didactic purpose, and the lengthy narratives which occupy the main portion of his "universal history." It can thus be said, in the kind of multicultural terms which Ibn Khaldun himself might have appreciated, that he seems to have neglected his cibar mitzvah.

We are not the first to argue that the apparently "mindless empiricism" of Ibn Khaldun's positivist historiography is, in fact, influenced by the principles of the Muqaddimah. There is a longstanding controversy among French and Arab historians of the Maghreb concerning the division in Kitab al- $\mathrm{Ibar}$ of the North African Berber tribes into botr and baran, and whether this is (or should be) linked to Ibn Khaldun's earlier theories of the relationship between rural/bedouin and urban/sedentary forces in the development of states. ${ }^{30}$ The various participants in this controversy at least agree that Ibn Khaldun did impose some kind of model on the genealogy of the various groups involved in North African history, and that the results do not correspond to data which can be found in independent sources.

\section{VII}

For Mali, in contrast to the Maghreb, there is no comparable information against which we can check Ibn Khaldun's narrative. If we acknowledge that this account of the early Mali rulers at least bears a strong resemblance to the model set forth in the Muqaddimah, what are the consequences for our own understanding of medieval Sudanic history? The possibilities stretch across a range whose polar positions are, at one end, the reduction of Ibn Khaldun's narrative to its structural/didactic principles and at the other, its acceptance as a fully accurate reconstruction of past events. It might be tempting to conclude that, given the evidence of the cyclical model underlying Ibn Khaldun's account, it has little value as evidence of "what actually happened" in the Mali empire. On the other hand, it is also possible to believe Ibn Khaldun's own implicit argument that his theory of dynastic succession derived precisely from prior and unprejudiced observation of cases like that of Mali.

Obviously neither of these somewhat caricatured positions is defensible. Even if Ibn Khaldun did impose his own views on the evidence derived from 
Mal1 and the appearance of Sekure (or even other historical elements) in modern Mande traditions derives from Ibn Khaldun's text, he could not have invented a typical Mande name such as Mari Jata and the basic information about the rise of the Mali empire. By the same token, it is hard to believe that Ibn Khaldun's construction of Sudanic history is not in some way influenced by his cyclical theory, since the Muqaddimah was completed in 1377 , some time before he even collected, let alone collated, most of his data on the Mali kings. Thus the chronology of Mali may also be the product of a political theory. Finally, the kinglist in Ibn Khaldun's Malı chronology does not bear much resemblance to present-day Mande genealogies, which are unllinearand distinguish mainly between older and younger branches. ${ }^{31}$

We are thus left with a historical source which has to be taken seriously but also read with a certain degree of reserve. Given the low probability of new evidence being discovered, any attempt to write a coherent account of the early Mali empire-particularly for school textbooks-will still have to rely on this imperfect document. But more scholarly histories should treat the genealogy presented by Ibn Khaldun with greater caution. Students of historiography may also follow the most exemplary feature of Ibn Khaldun's own practice and use the case of the Mali chronology to explore the more general problems raised not only by what we take to be the experiences of the past but also by the contexts in which the records of such experiences are created.

\section{Notes}

1 The relevant sections of this text are carefully translated and annotated in JFP Hopkins and N Levtzion, Corpus of Early Arabic Sources for West African History (Cambridge), 333-36

2 Ibn Khaldun, The Muqaddimah an Introductıon to History, trans Franz Rosenthal 3 vols New York, 1958), 1265

3 Maurice Delafosse, Haut-Sénégal-Niger (3 vols Parıs, 1972), Nehemia Levtzıon, Ancient Ghana and Malı (London, 1973), Madina Ly-Tall, Contributıon à l'histoure de l'empire du Malı (XIIle XVle siècle) (Dakar/Abidjan, 1977), Djibril Tamsir Niane, Recherches sur l'Empire du Malı au Moyen Age (Parts, 1975)

4 Transcript of the Sunjata Epic Conference, 13-15 November 1992, Institute for the Advanced Study and Research in the African Humanities at Northwestern University, pp 3-4, $15 \mathrm{ff}$ (transcript avalable at Northwestern University Africana lıbrary, papers (including onc by Jansen who did not attend the conference) to be published as Ralph A Austen, ed, In Serrch of Sunjata the Mande Epic as History, Literature and Performance (Bloomungton, 1996)

5 The Northwestern discussion focused on the passages in Ibn Khaldun referring to Sunjata rather than the lengther series of reigns under consideration here

6 Including one of the present authors (Austen), who organized the conference

7 Ibn Khaldun names four informants, giving the dates when he spoke to them (but not always precisely which data each provided), and adds that "we have heard" of events in the very late fourteenth century, when his own account was being written

8 The text calls him a son, Levtzion (Ancient Ghana and Mali, 65) interpolated a certain Faga Laye (taken from Niane's research on oral tradition) in order to make him a grandson It $1 \mathrm{~s}$ unimportant for our purposes whether Musa was the son or the grandson, because both classifications present him as a direct descendant of Mari-Jata

9 Levtzion, Ancient Ghana and Mall, 68-72, 78ff

10 For the meaning of the younger brother in Mande claims for legitımate rule see Jan 
Jansen, "The younger brother and the stranger, in search of a status discourse for Mande" (paper for the Mande Studies Association Conference, Leiden, March 1995)

11 Ibn Khaldun notes that his informants could give him no genealogy for Mari Jata I (Hopkins/Levtzion, Corpus, 333) Current Mande oral traditions do provide Sunjata with a long line of illustrious ancestors, extending back to Mecca However, even here there is some suggestion of a disruption through the statement in many versions of the epic that Sunjata's jamu (clan name), Keita, is not the same as that of his father, Konate This datum (buttressed by the accompanying accounts of Sunjata's triumphant return from exile in the north), has led some local informants and one expatriate historian to speculate that the founder of the Mali empire was a Sahelian invader (the griot Seydou Camara cited in Charles S Bird, "The Production and Reproduction of Sunjata", in Austen, In Search of Sunjata, Dierk Lange, "Das alte Mal1 und Ghana Der Beitrag der Oraltradition zur Kritik einer historiographischen Fiktion," Historische Zeltschrift, 255 (1992), 587623

12 We have substituted this term for "group feeling," which is Rosenthal's translation of asabiyah

13 Ibn Khaldun, Muqaddimah, 1 278-80

14 Ibid, 1281

15 Hopkıns/Levtzion, Corpus, 289-90, $295 \mathrm{Ibn}$ Battuta was a contemporary of Ibn Khaldun who visited Mali in the mid-fourteenth century His accounts of travel to India (but not to sub-Saharan Africa) are discussed at some length in the Muqaddimah, where Ibn Khaldun reproaches himself for having assumed them to be untrue (Muqaddimah, I 369-71)

16 Abu Bakr is possibly a basis for Mande Bori/Mande Bakarı, Sunjata's brother and huntung companion in twentieth-century traditions However, the name "Bakarl" is very common in West Africa today, and therefore its ongin cannot be traced On the contrary, no one bears the name "Sekura/Sekure"," which makes plausible that Ibn Khaldun's Sakura is one and the same as the Sekure of Mande traditions

17 Madina Ly-Tall, Seydou Camara, and Bouna Dioura, L'historre du Mandé d'apres Jelı Kanku Madı Jabaté de Kéla (Parıs, 1987), 74-75, Jan Jansen, Edgar Duntjer, and Boubacar Tamboura, L'épopée de Sunjara d'après Lansine Diabate de Kela (Le1den, 1995), 191-96, Ly Tall, 1977, Contribution, 201-03, provides a very similar account in which the servile ruler is named Djonsombe ("Slave Sombe")

18 Ibn Khaldun served for some tıme under a regime in Egypt, the Mamluks, whose very name indicates their ongin and continued recruitment from the ranks of imported slave soldiers, Mande traditionalists would know of the Ngolossi dynasty of the eighteenth-to mineteenth-century Segu empire, which traced its origin to a coup by a leader of the ton-jon, a servile (Jon) military formation which constituted the power base of this state (unlıke the Mamluks, the Ngolossi did reproduce themselves via patrilineal descent rather than newly imported slaves)

19 David C Conrad, "Searching for History in the Sunjata Epıc The Case of Fakol,," HA, 19(1992), 167

20 This is particularly plausible for Sekure, since the few oral references to him come from a small region etther the village of Kela or the nearby Upper Gumea town of Siguin (see references in note 17 above) Since the reign of Sekure occurs after Sunjata's death, it does not form part of the standard epic performance and the two earliest recordings of it in Sigurn (LyTall, Contribution) and Kela (Ly-Tall et al, Historre du Mandé) had to be induced by direct questioning It is possible that further inquiries would reveal a wider provenance of this figure in Mande tradition and also provide more understanding of the relationship between oral and written sources

21 John Hunwick reports (private communication) that the sixteenth century Timbuktu scholar, Ahmad Baba, was quite famliar with Kltab al ${ }^{c}$ Ibar which he cites in his own essay on slave trading in Africa Alsmad Baba's essay was known and quoted extensively by the nineteenth-century Sokoto scholar and Jihadist Ahmadu Bello (s/o Usman dan Fodıo), see Ralph A Austen, "Orality, Littracy and Literature a Comparison of Three West African Heroic Narratıves" in John Hunwick and Nancy Lawler, eds, A Cloth of Many Silks a Festschrift for Ivor Wilks (Evanston, 1996) 
22 Ralph A Austen, "The Historical Transformation of Genres Sunjata as Panegync, Folktale, Epic and Novel" in 1dem, In Search of Sunjata An alternative explanation for the silence of written sources is that up unt1 1879 we have no first-hand accounts of any kind concerning travel in the Kita Kangaba-Kouroussa triangle of southern Mali and Upper Gunea-the core area of post-1mperial Keita dynastic authority and thus of the Sunjata tradition Jan Jansen, "De draaiende put een studie naar de relatie tussen het Sunjata-epos en de samenleving in de Haut Niger (Mal1) ( $\mathrm{Ph} \mathrm{D}$, University of Leiden, 1995), chapter 3

23 See especially Erwin I J Rosenthal, Polttical Thought in Medieval Islam (Cambridge, 1968), 67-109 passim where the highly literary "murrors" tradition is compared unfavorably with the "empincist Ibn Khaldun" (69), characterized as "not a dispenser of advice to rulers and administrators but a political scientist who probes into the causes underlying the historical and political process" (80), for some suggestive linking of Ibn Khaldun to authors of the "murrors" school see Aziz al-Azmeh, Ibn Khaldun an Essay in Interpretation (London, 1982), $145 \mathrm{ff}$

24 Hopkins and Levtzion's (Corpus, 317) translation of the complete title is "The Book of Examples and the Register of Subject and Predicate [or the Ongin and History], on the Days of the Arabs, the Persians and the Berbers," the root and associated meanings ("admomtion, warning") of $c_{l} b a r$ suggest that "exemplar" is a better translation for this key term

25 He wrote a very detaled autobıgraphy and there are many other sources for his public career, see Franz Rosenthal, "Ibn Khaldun's Life" in Muqaddımah, xxix lxvi1

26 Lous Marlow, "Some Uses of Historical Anecdote in Medieval Islamic Advice Literature" (unpublished paper presented at the Middle East Studies Association meeting, November 1993)

27 Ibn Khaldun, Muqaddımah, 15

28 The technical term for such chains, isnad, is very prominent in the collections of extra-Quranic traditions upon which much of Islamic law (shart ${ }^{c} a$ ) is based

29 Ton Khaldun, Muqaddmah, 16

30 Charles-André Julien (ed Roger Le Tourneau), Historre de l'Afrique du Nord de la conquête arabe a 1830 (Pans, 1956), 22-26, Abdallah Larou1, The History of the Maghrıb an Interpretive Essay (Princeton, 1977), 219-23, Az1z al-Azmeh, Ibn Khaldun in Modern Scholarship a Study in Ortentaltsm (London,1981), 199-222

31 Jansen, "Younger Brother" 